\title{
Carrot or stick? An investigation into motivation orientations in learning English among Hong Kong Chinese students
}

Recompensa ou punição? Uma investigação sobre orientações motivacionais na aprendizagem de inglês de alunos chineses em Hong Kong

Ruth Wong*

Hong Kong Institute of Education

RESUMO: Este artigo apresenta os resultados de um estudo realizado com estudantes chineses do ensino médio, tendo em vista suas orientaçōes motivacionais para aprender inglês. O estudo analisou grupos de estudantes femininos e masculinos, tendo como suporte teórico o conceito de "motivação extrínsica e intrínsica" de Gardner e Lambert (1972). Estes resultados terão implicaçōes pedagógicas significativas, ajudando os educadores a identificar estratégias mais apropriadas para grupos diferentes de estudantes chineses de segunda língua.

PALAVRAS-CHAVE: orientação motivacional extrínsica, orientação motivacional intrínsica, Gardner.

ABSTRACT: This paper publishes the results of a study of Hong Kong Chinese upper secondary students (Form 4 and Form 6) regarding their motivation orientations for learning English. The study analysed male and females student groups using Gardner and Lambert's (1972) 'extrinsic and intrinsic motivation' theoretical framework in order to elicit the most revealing results from the data. Findings will have meaningful implications for pedagogy, helping educators identify strategies more appropriate to distinct Chinese-speaking second-language student groups.

KEYWORDS: extrinsic motivation orientation, intrinsic motivation orientation, Gardner.

*wongmh@ied.edu.hk 


\section{Introduction}

Motivating students to learn is an essential function, indeed responsibility, of education. Most Hong Kong secondary schools focus on students when designing English syllabuses, typically with teachers setting materials according to their students' needs. To become even better student-oriented schools, it behooves administrators and teachers alike to understand student motivations in learning English.

Research shows that both intrinsic and extrinsic motivations are involved in second language learning (GARDNER; LAMBERT, 1972). The motivational orientations proposed by Gardner and Lambert form the theoretical framework of this study. Student motivation naturally affects how much a student desires to participate in the learning process.

Students who are intrinsically motivated undertake an activity for the enjoyment it provides and the feelings of accomplishment it evokes. Students who are extrinsically motivated strive to reach goals in order to obtain some reward or avoid some punishment external to the activity itself. These students may also be more exam-oriented than those students with intrinsic motivation. Students with different motivation patterns have different learning styles. Those with intrinsic motivation may enjoy learning English through music, TV programmes or movies, whereas extrinsically motivated students would probably concentrate more on learning grammar and reading textbooks. In order to facilitate effective ESL teaching, it will therefore be necessary to investigate ESL student motivations for learning English. This study will investigate whether Hong Kong upper secondary students tend to have a stronger extrinsic motivation or intrinsic motivation. An attempt will also be made to compare any motivational differences according to gender lines.

\section{Intrinsic and extrinsic motivation orientation}

There are many facets of motivation available to be scrutinized (AMES, 1984; BANDURA, 1993; CLEMENT, 1980; DECI; RYAN, 1985; ECCLES; WIGFIELD, 1995; LOCKE; LATHAN, 1994; OXFORD; SHEARIN, 1994; SALILI, 1995; SCHUMANN, 1978; WEINER, 1979; WILLIAMS; BURDEN, 1997). Many studies have also been conducted to investigate motivations for learning other languages in different contexts (DORNYEI, 2001; NOEL; PELLETIER; CLEMENT; VALLERAND, 2000; USHIODA, 2003). This study will only focus on whether students learn English because of an integrative reason or a practical reason. Gardner also 
proposed a revised socio-educational model in 2001 which includes three elements: (1) motivated individuals expand efforts to learn another language, (2) motivated individuals want to achieve a goal, and (3) motivated individuals will enjoy the task of learning the foreign / second language; however, the revised socio-educational model Gardner (2001) proposed was not clearly classified or distinguished from one category to another. The model Gardner and his colleague proposed in 1972 was clearly categorized, hence many studies still adopt the original revised version, rather than the revised model (see GIOVANNI; SIU, 2002; NILSSON, K.; STOMBERG, 2008). Also, this study intends to determine different motivation orientation biases between female and male students, if any. Thus, it is necessary to adopt a model which can clearly categorise this complicated construct. The original Gardner and Lambert (1972) socio-educational model will be appropriate for this study.

Gardner and Lambert's (1972) socio-educational model is considered one of the most prominent motivation theories, as well as one of the most significant models for the development of motivation and language learning (DORNYEI, 1994). Dornyei (1994, p. 273) commented that

the most significant milestone in the history of L2 motivation research is Gardner and Lambert's discovery that success is a function of the learner's attitude toward the linguistic-cultural community of the target language, thus adding a social dimension to the study of motivation to learn an L2... By combining motivation theory with social psychological theory, the model of L2 motivation that Gardner and Lambert developed was much more elaborate and advanced than many contemporary mainstream psychological models of motivation, in that it was empirically testable and did indeed explain a considerable amount of variance in student motivation and achievement.

Gardner (1985) describes two distinct orientations on motivation. The first is motivation as an element of an internal attribute which serves as an internal drive to enable a human to perform a task. The second is motivation as an external attribute, i.e. motivation can be created by external force or reward. A hybrid perspective is that motivation can be an internal attribute and, at the same time, the result of an external force (GARDNER, 1996). The socio-educational model possesses this hybrid perspective. According to Gardner (1996), motivation has most frequently been characterised with two orientations. They are intrinsic and extrinsic motivation orientations. Intrinsic motivation orientation refers to reasons for L2 learning that are derived from one's inherent pleasure and interest in the activity; the activity is undertaken 
because of the spontaneous satisfaction that is associated with it. Extrinsic motivation orientation refers to reasons that are practical - not from an inherent interest in the activity. Gardner (1996) however argues that motivation must be a characteristic of the individual and that it cannot be created out of nothing by an external force. An external force can arouse motivation, as when a teacher attempts to motivate students. The potential to be motivated must already exist and be a property of the student in order for a particular pedagogical technique to be effective.

Gardner's (1985) theory brought significant influence to the development of motivation theories and approaches in the following decades (see AMES, 1984; ATKINSON; FEATHER, 1966; BANDURA, 1993; CLEMENT, 1980; DECI; RYAN, 1985; ECCLES; WIGFIELD, 1995; GILES; BYRNE, 1982; LOCKE; LATHAN, 1994; OXFORD; SHEARIN, 1994; PINTRICH; SCHUNK, 1996; SALILI, 1995; SCHUMANN, 1978; WEINER, 1979; WILLIAMS; BURDEN, 1997) and possibly generations to come. In the context of the Hong Kong Chinese setting, Gardner's extrinsic and intrinsic motivational constructs are appropriate for testing and evaluating the students for their motivations in learning English.

\section{Gender and motivation orientation}

There exists a common understanding that females have a better gift of language than males. Ample studies have tried to prove or disprove this, but research to-date has not found any conclusive evidence, indeed, results often contradict one another. For example, Hagborg (1995) indicated that there were no significant gender differences on 'mastery motivation' intrinsic motivational components. Meece and Jones (1996) also examined gender differences in self-reported fifth- and sixth-grade student confidence levels, motivational goals, and learning strategies in whole-class and small-group sessions. Overall, results revealed few gender differences and indicated that students had reported greater confidence and mastery motivation in small-group lessons (Also see BAR-TAL et al., 1984; KINICKI et al., 1985). Chandler et al. (1981, p. 221) stated that, "The fact that the differences ... were generally small leads one to question the meaningfulness of these differences except perhaps in selected instances." That is, according to Chandler et al. (1981), no significant differences could be identified between male and female student motivations.

There are other studies attempting to explain gender differences in motivation which can be divided into two streams: those stating females have 
stronger overall motivation, and those stating the opposite. However, a study by Boggiano and Barrett (1992) found a different kind of result, one indicating that females are more often extrinsically motivated than males, and that males are intrinsically motivated, and interestingly, have fewer incidents of depression than females. Related research has been conducted by Basow and Medcalf (1988), Erkut (1983), McHuge et al. (1982), Post (1981), Sweeny et al. (1986) and Wolleat et al. (1980), Brandon (1990), Niemivirta (1997), Wang and Staver (1997). Indeed, extensive research has been conducted into learning motivations by different groups of students. But it is doubtful whether these results are applicable to the English learning context of Hong Kong students. This study, therefore, aims to fill this gap.

\section{Purpose of study}

This study has as its objective the understanding of the motivational orientation of Hong Kong upper secondary school students (Grades 10-12). Thus, a practical and appropriate teaching methodology could be adopted to improve student motivation to learn English and improve proficiency. There are two constituents under this main objective:

Research Question 1:

1. Are Hong Kong Chinese students more intrinsically or extrinsically motivated?

Research Question 2:

2. Are there any motivational differences that appear along gender lines?

To answer these questions, the motivational orientation of Hong Kong upper secondary students generally must be determined first. Educators could then better understand Hong Kong Chinese student motivations, which are crucial determinants in their second language learning. Appropriate teaching strategies and procedures will then be determined and employed accordingly.

\section{Methodology}

\section{Participants}

156 Hong Kong Chinese upper secondary students from 2 different secondary schools volunteered to participate in this study (Note: There are 7 
forms in the Hong Kong secondary education system. Lower secondary refers to Form 1 through Form 3; and upper secondary refers to Form 4 through form 7. Form 1 contains the youngest students and Form 7 the eldest). Participants in this study were aged between 15 and 19 years of age, inclusive for whom English was a compulsory subject. All had been learning English for more than 12 years.

Taking part in the study were 82 female students and 74 male students from Form 4 (Grade 10) and Form 6 (Grade 12), divided by gender according to the following cross-tabulated table:

TABLE 1

Summary for the participants $(\mathrm{N}=156)$

\begin{tabular}{lccc}
\hline & Male & Female & Total \\
\hline F6(Grade 12) & 35 & 42 & 77 \\
F4(Grade 10) & 39 & 40 & 79 \\
Total & 74 & 82 & 156 \\
\hline
\end{tabular}

\section{Instruments}

For the purpose of this study, students answered a questionnaire regarding their views on learning English. Later, some participants were randomly chosen and interviewed by the researcher.

\section{Questionnaire}

The questionnaire was comprised of 16 different items, each with a five-point scale ranging from Strongly Agree (1) to Strongly Disagree (5). Of the 16 items, 8 measured respondent intrinsic motivation and 8 measured extrinsic motivation. Items (1), (2), (5) to (8), (14) and (16) were designed to measure extrinsic motivation orientation, whereas items (3), (4), (9) to (13) and (15) examined intrinsic motivation orientation. The 8 items of each motivation orientation were designed to repeatedly elicit each participant response on the same motivation orientation so as to ensure the validity and integrity of the answers.

Two questions on personal particulars (gender and current school form) were also required for statistical analysis purposes. Also, in order to ensure the questionnaire was able to capture student attitudes towards learning English, it was a revised version based on results of an informal pilot study of students 
from the target population. The questionnaire was worded in simple English to ensure its comprehension by respondents. Respondents were reminded that their participation was completely voluntary. 'Informed consent' forms were distributed. The researcher explained the questionnaire to the subjects, assured them that the information they provided would be used for research purposes only, and that their names were not required in the survey. Respondents were given 15 minutes to answer the questionnaire. Extra time would be given if so requested by the respondents. The researcher also remained available in the classroom for consultation in the event of student questions.

\section{Interviews}

Face-to-face semi-structured interviews were conducted after a preliminary analysis of the questionnaire results. There were areas in the questionnaire results which required explanation - interviews filled this gap by providing further explanation and triangulation. Several prompting questions were prepared to elicit explanations from the respondents regarding some questionnaire items. Follow-up questions would then be asked if the researcher decided that even more detail was required.

Ten students from 2 different school levels were randomly interviewed in the 'non-threatening environment' of a counselling room, thus encouraging the respondents to express their unbiased feelings about learning English. The researcher first thanked them for participating, then explained to them the purpose of the interview and how it would be structured. Respondents were then reminded that the interview would be recorded, and that their responses and names would remain confidential - consequently their names have been replaced with aliases. Interviews were conducted in Cantonese, the language with which respondents felt most comfortable.

\section{Data analysis}

Descriptive analyses were used to describe the basic features of the data in this study, thus producing simple summaries of results found for the motivation orientation of Hong Kong students learning English.

Each 8-item questionnaire was subjected to two reliability tests to check for internal consistency of both intrinsic and extrinsic motivation. The reliability coefficients (Cronbach alphas) were high, verifying that the internal consistency of the 16 items in the questionnaire was also high (see TAB. 2). 
The qualitative data obtained was translated from the respondents' first language (Cantonese) into English for codification. The data were analysed manually by categorising the answers based on specific markers. This classification enabled the researcher to effectively further investigate the statistical results, and transcripts were also used to supplement the answers found within the statistical data.

\section{Results and discussion}

TAB. 2 summarizes the descriptive data. Variables include intrinsic motivation orientation and extrinsic motivation orientation.

TABLE 2

Summary statistics and reliability estimation for the questionnaire $(\mathrm{N}=156)$

\begin{tabular}{l|ccccc}
\hline \multicolumn{1}{c|}{ Variables } & Subjects & Items & Mean & $\begin{array}{c}\text { Std. } \\
\text { Deviation }\end{array}$ & $\begin{array}{c}\text { Cronbach } \\
\text { Alpha } \\
\text { (reliability) }\end{array}$ \\
\hline $\begin{array}{l}\text { Intrinsic motivation } \\
\text { orientation }\end{array}$ & 156 & 8 & 3.88 & 0.822 & 0.788 \\
$\begin{array}{l}\text { Extrinsic motivation } \\
\text { orientation }\end{array}$ & 156 & 8 & 4.54 & 0.868 & 0.792 \\
\hline
\end{tabular}

\section{Motivation orientations in learning English among Hong Kong Chinese students}

Student motivation concerns the reasons and goals that underlie student involvement or non-involvement in academic activities. Although students may be equally motivated to perform a task, the sources of their motivation may differ. This study found that Hong Kong Chinese secondary school students have stronger extrinsic motivation orientation to learn English relative to intrinsic motivation orientation. These results echoed Giovanni and Siu's (2002) findings that the intrinsic motivation of Hong Kong college students was discouraged by the college environment. A possible explanation for this is the approach of public examinations that students must face in the following year. Students must sit a public examination to determine whether they can continue studying (Form 4 students), or whether they can be admitted to university (Form 6 students). A passing grade in English is a prerequisite for university acceptance. Also, teachers inevitably put more emphasis on the public examinations and very often use it as a 'motivator' to encourage students 
to work harder. In this situation, students will generally experience a much stronger extrinsic motivation than intrinsic motivation, as English is perceived as a highly relevant subject to their studies and career.

As higher English skills correlate to higher career prospects (BOND, 1996), English is considered an important subject with strong practical value in the Chinese view. Parents try their utmost to ensure their children are accepted by an EMI (English Medium Instruction) school, as these schools achieve higher university entrance rates. Because of this expectation from teachers, parents and the students themselves, students perceive English to have high practical value. As one interviewee responded, "Learning English is the only way out if you want to have a good job secured or a good life ahead of you..." (Paul Ho).

However, the fact that Hong Kong Chinese students are weaker in intrinsic motivation may also be directly related to various social factors. Students in Hong Kong are known to be passive learners, and some would describe the Hong Kong education system as using a 'spoon-fed' methodology, one which damages intrinsic motivation to learn English. Besides, Hong Kong secondary school students also prefer to use Cantonese over English whenever possible (LUK; LIN, 2007). In this environment, it is difficult to cultivate an intrinsic motivation to learn English in Hong Kong students.

\section{Motivation orientation: Gender differences - Quantitative}

This study found that overall, Hong Kong Chinese students possessed a stronger extrinsic motivation to learn English. However, this study would be of even higher value and interest if it could prove whether male and female students had differing motivation orientations to learn English. TAB. 3 shows the gender differences between extrinsic and intrinsic motivation.

\section{TABLE 3}

Summary Statistics and reliability estimation for the questionnaire according to gender $(\mathrm{N}=156)$

\begin{tabular}{l|l|cccc}
\hline \multicolumn{2}{c|}{ Variables } & Subjects & Mean & $\begin{array}{c}\text { Std. } \\
\text { deviation }\end{array}$ & $\begin{array}{c}\text { Cronbach } \\
\text { alpha } \\
\text { (reliability) }\end{array}$ \\
\hline Intrinsic & Female students & 82 & 4.34 & 0.56 & 0.756 \\
motivation & Male students & 74 & 3.42 & 1.58 & 0.743 \\
Extrinsic & Female students & 82 & 4.20 & 0.42 & 0.822 \\
motivation & Male students & 74 & 4.88 & 0.11 & 0.867 \\
\hline
\end{tabular}




\section{Motivation orientation: Gender differences - Qualitative}

a) Female students have stronger intrinsic motivation orientation than extrinsic motivation. The reasons for this are simple: females tend to be more socially dependent and they are more eager to integrate with a social norm, as they see other people's criticism as relatively more important than do males. As one female interviewee indicated, "I don't want to be left out from my circle of friends. We all love American pop stars. Without English, how can I communicate with my friends and keep myself updated with my idols' news?" (Sandy Liu).

b) Male students have stronger extrinsic motivation orientation than intrinsic motivation. The reason could be their thinking is more career-oriented than females, thus learning English is mainly for vocational purposes. As explained by one of the respondents, "If you can speak English, not only will you get a good job, you will also have a better chance to be promoted and work overseas. Hong Kong is just a small city, I want to extend my career overseas."

c) Male students have stronger extrinsic motivation orientation than female students. As male students tend to be more career-oriented, their extrinsic motivation is thought to be stronger, but more recently, the same motivation applies to female students. Female students now receive the same education as male students. The traditional Chinese thinking of 'only male children should receive an education' is no longer the social expectation. Female students are also expected to work, and they can be equally career-oriented as male students. The rise of gender equality raises female extrinsic motivation to learn, especially academically. "I learn English isn't because I like languages. It's because I want to have a good job. It's hard to get a job in Hong Kong if you don't know English" (Sandy Siu).

d) Female students have stronger intrinsic motivation than male students. A common viewpoint, as explained by one of the female respondents was, "I believe girls are better at appreciating the language. We girls wouldn't mind singing English songs in the class but the boys do. I believe no one can understand the beauty of English songs unless you open your mouth and sing them... girls are usually more sentimental and I like expressing my feelings through writing poetry and probably that's the reason of my obsession to Jane Austin's works" (Brenda Chan). 
Generally speaking, this study found that female students had stronger intrinsic motivation while male students possessed stronger extrinsic motivation - regardless of whether the two motivation orientations were compared across gender groups or not. In other studies, female students were also found to have stronger intrinsic motivation. Skaalvik and Skaalvik (2004) found female students had higher intrinsic motivation for learning Norwegian than did male students. Nilsson and Stomberg (2008) also revealed that female nursing students have higher intrinsic motivation than male students. Jacobsson (2000) found that female students had higher intrinsic motivation than males. In addition it was found that female students work harder, as well as having more thought-out strategies for their studies. Males students were found to have stronger extrinsic motivation than girls. For example, in Baer's (1997) work, he found that female creativity decreased markedly under extrinsic constraints, but boys' did not because they perceive outcomes an important source of motivation. This could be a highly likely explanation for the gender differences in the findings of this study.

\section{Limitations of study}

There are two limitations to be acknowledged and addressed regarding this study. The first concerns the cross-disciplinary nature of this research, which aimed merely to investigate Hong Kong upper form secondary student motivations to learn English - specifically not as a cross-disciplinary study. The second limitation relates to the extent to which the findings can be generalized beyond the participants studied. The number of participants in this study is too limited for broad generalizations. Further empirical evaluations, however, are needed to replicate the findings in different contexts and surroundings.

\section{Conclusion}

This study found that Hong Kong upper secondary school students overall have stronger extrinsic motivation than intrinsic motivation orientation because of the need for further studies and career pursuits. Social factors like teachers, parents and social pressure also played a significant role in affecting their motivation orientation to learn English. Females, however, were found to have stronger intrinsic motivation than males to learn English as supported by Oxford and Nyikos (1989).

If this is the case, it has implications for teaching pedagogy - ESL teachers should be using differing strategies to motivate upper secondary 
students of different genders. If teachers are teaching in a single-gender school, the issue can be more easily dealt with. That is, when teaching boys, teachers can simply focus more on the practical values of learning English, e.g. using themes that are closely related to their future (such as career). Likewise, when students are female-only, teachers of English can use a more integrated approach, such as using language arts like poems, songs, drama and stories.

However, as English classes in Hong Kong are usually co-ed, teachers should adopt a hybrid approach, as it will likely motivate more students to learn English. A practical example of a hybrid approach would be to use language-arts to address themes such as career, family and furthering studies, or perhaps to write a poem concerning a dream job or listen to songs about ambitions.

Ultimately, to compensate for different male and female motivations in learning English, teachers should adjust their teaching approach to enable students to learn English in the way that is uniquely best for them.

\section{References}

AMES, C. Competitive, cooperative and individualistic goal structures: A cognitive motivational analysis. In: AMES, R.; AMES, C. (Ed.). Research in Motivation in Education. Orlando, Florida: Academic Press, 1984. p. 177-207. ATKINSON, J. W.; FEATHER, N. T. (Ed.). A Theory of Achievement Motivation. New York: Robert E. Krieger, 1966.

BANDURA, A. Perceived Self-Efficacy in Cognitive Development and Functioning. Educational Psychologist, v. 28, p. 117-48, 1993.

BAR-TAL, D., GOLDBERG, M.; KNANNI, A. Causes of success an failure and their dimensions as a function of SES and gender: A phenomenological analysis. British Journal of Educational Psychology, v. 54, p. 51-61, 1984.

BASOW, S. A.; MEDCALF, K. L. Academic achievement and attributions among college students: Effects of gender and sex typing. Sex Roles, v. 19, n. 9/ 10, p. 555-567, 1988.

BAER, J. Gender differences in the effects of anticipated evaluation on creativity. Creativity Research Journal, v. 10, n. 1, p. 25-31, 1997.

BOGGIANO, A. K.; BARRETT, M. Gender differences in depression in children as a function of motivational orientation. Sex Roles, v. 26, n. 1-2, p. 11-17, 1992. BOND, M. H. (Ed.). The Handbook of Chinese Psychology. Hong Kong: New York: Oxford University Press, 1996. 
BRANDON, P. R. Gender Differences in Educational Attainment among Asian Americans in the High-School-and-Beyond Senior-Cohort Third Follow-Up Survey. Paper presented at the Annual Meeting of the American Educational Research Association (Boston, MA, April 16-20, 1990).

CHANDLER, T. A.; SHAMA, D. D.; WOLF, F. M.; PLANCHARD, S. K. Multi-attributional causality: A five national samples study. Journal of CrossCultural Psychology, v. 12, p. 207-221, 1981.

CLEMENT, R. Ethnicity, contact and communicative competence in a second language. In: GILES, H.; ROBINSON, W. P.; SMITH, P. M. (Ed.). Language: Social Psychological Perspectives, 1980. p. 147-154.

CONDRY, J.; CHAMBERS, J. Intrinsic motivation and the process of learning. In: LEPPER, M. R.; GREENE, D. (Ed.). The Hidden Costs of Rewards. New Jersey: Lawrence Erlbaum Associates, 1978. p. 61-84.

DECI, E. L.; RYAN, R. M. Intrinsic Motivation and Self-Determination in Human Behaviour. New York: Plenum Press, 1985.

DORNYEI, Z. Motivation and motivating in foreign language classroom. The Modern Language Journal, v. 78, p. 273-284, 1994.

DORNYEI, Z. Teaching and Researching Motivation. London: Longman, 2001. ECCLES, J. S.; WIGFIELD, A. In the mind of the actor: The structure of adolescents' achievement task values and expectancy-related beliefs. Personality and Social Psychology Bulletin, v. 21, p. 215-225, 1995.

ELLIS, R. The Study of Second Language Acquisition. Oxford; New York: Oxford University Press, 1994.

ERKUT, S. Exploring sex differences in expectancy, attribution, and academic achievement. Sex Roles, v. 9, n. 2, p. 217-231, 1983.

GARDNER, R. C.; LAMBERT, W. E. Attitudes and Motivation in Second Language Learning. Rowley, Mass.: Newbury House, 1972.

GARDNER, R. C. Social Psychology and Language Learning: The Role of Attitudes and Motivation. London: Ontario: Edward Arnold, 1985.

GARDNER, R. C. Motivation and second language acquisition: Perspectives. Journal of the Canadian Journal of Applied Linguistics, 18(2), p. 19-42, 1996.

GARDNER, R. C. Language Learning Motivation: the student, the teacher, and the researcher. Texas Papers ion Foreign Language Education, v. 6, p. 1-18, 2001. GILES, H.; BYRNE, J. L. An intergroup approach to second language acquisition. Journal of Multilingual and Multicultural Development, v. 3, p. 17-40, 1982. 
GIOVANNI, M.; SIU, C. M. Y. Trait intrinsic and extrinsic motivations, academic performance, and creativity in Hong Kong college students, Sep/Oct, 2002. Journal of College Student Development. Disponível em: <http://findarticles.com/ p/articles/mi_qa3752/is_200209/ai_n9132496>. Accesso em: 20 June 2008. HAGBORG, W. J. Gender and Motivational Orientation among High School Students. Paper presented at the Annual Meeting of the American Psychological Association (New York, NY, August 1995).

JAKOBSSON, A. K. Motivation and Learning from a Gender Perspective. A study of students at gymnasium in theoretical program. An unpublished thesis of Göteborg, Göteborgs Universitet: Acta Universitatis Gothoburgensis, 2000.

KINICKI, A. J.; GRIEFFETH, R. W. The impact of sex-role stereotypes on performance ratings and casual attributions of performance. Journal of Vocational Behaviour, v. 27, p. 155-366, 1985.

LOCKE, E. A.; LATHAN, G. P. Goal setting theory. In: O’NEIL, H F, Jr; DRILLINGS, M. (Ed.). Motivation: Theory and Research, 1994. p. 13-29.

LUK, J. C. M.; LIN, A. M. Y. Classroom Interactions as Cross-Cultural Encounters: native speakers in EFL lessons. Mahwah, N.J.: Lawrence Erlbaum Associates, Inc., 2007

McHUGE, M. C.; FISHER, J. E.; FRIEZE, I. H. Effect of situational factors on the sled-attributions of females and makes. Sex Roles, v. 8, n. 4, p. 389-397, 1982.

MEECE, J. L.; JONES, M. G. Gender differences in motivation and strategy use in science: Are girls rote learners? Journal of Research in Science Teaching, v. 33, n. 4, p. 393-406, 1996.

NIEMIVIRTA, M. Gender Differences in Motivational-Cognitive Patterns of SelfRegulated Learning. Paper presented at the Annual Meeting of the American Educational Research Association (Chicago, IL, March 24-28, 1997).

NILSSON, K.; STOMBERG, M. I. W. Nursing students motivation toward their studies - a survey study. BMC Nursing 7(6). Disponível em: <http:// www.biomedcentral.com/1472-6955/7/6>. Acesso em: 20 June 2008.

NOEL, K. A.; PELLETIER, L. G.; CLEMENT, P.; VALLERAND, R. J. Why are you learning a second language? Motivational orientations and selfdetermination theory. Language Learning, v. 50, n. 1, p. 57-85, 2000.

OXFORD, R. L.; NYIKOS, M. Variables affecting choice of language learning strategies: A pilot study. Modern Language Journal, v. 73, p. 291-300, 1989.

OXFORD, R. L.; SHEARIN, J. Language learning motivation: expanding the theoretical framework. Modern Language Journal, v. 78, p. 12-28, 1994. 
PINTRICH, P. R.; SCHUNK, D. H. Motivation in Education: Theory, Research and Application. Englewood Cliffs, NJ: Prentice Hall, 1996.

POST, R. D. Casual explanations of male and female academic performance as a function of sex-role biases. Sex Roles, v. 7, n. 7, p. 691-698, 1981.

SALILI, F. Explaining Chinese motivation and achievement: Culture, motivation and achievement. In: MAEHR, M. L.; PINTRICH, P. R. (Ed.). Advances in Motivation and Achievement: Culture, motivation and achievement. Greenwich, CT: JAI, 1995.

SCHUMANN, J. H. The acculturation model for second language acquisition. In: GINGRAS, R. (Ed.). Second Language Acquisition and Fore, 1978.

SKAALVIK, S.; SKAALVIK, E. M. Gender differences in math and verbal self-concept, performance expectations, and motivation. Sex Roles, v. 50, n. 3/4, p. 241-52, 2004.

SWEENEY, P. D.; ANDERSON, K.; BAILEY, S. Attribution style in depression: A meta-analystic review. Journal of Personality and Social Psychology, v. 38, p. 254274, 1986.

USHIODA, E. Motivation as a socially mediated process. In: LITTLE, D.; RIDLEY, J.; USHIODA, E. (Ed.). Learner Autonomy in the Foreign Language Classroom: teacher, learner, curriculum and assessment. Dublin: Authentik, 2003. p.90-102.

WANG, J.; STAVER, J. R. An empirical study of gender differences in Chinese students' science achievement. Journal of Educational Research, v. 90, n. 4, p. 25255, 1997.

WEINER, B. A Theory of Motivation for some Classroom Experiences. Journal of Education Psychology, v. 71, p. 3-25, 1979.

WILLIAMS, M.; BURDEN, R. Psychology for Language Teachers. Cambridge: Cambridge University Press, 1997.

WOLLEAT, P. L.; PEDRO, J. D.; BECKER, A. D.; FENNEMA, E. (1980). Sex differences in high school students' casual attributions of performance in mathematics. Journal for Research in Mathematics Education, v. 11, n. 5, p. 356-366, 1980 . 


\section{Appendix}

\section{Motivations for Learning English}

I would like to find out what motivates you to learn English. Please look at the statements below and indicate how much you agree or disagree with them. Use a black / blue ball pen or pencil to circle the number that corresponds to your own opinions. If you make a mistake, please correct it with a rubber or correction fluid.

\begin{tabular}{|c|c|c|c|c|c|c|}
\hline & I want to learn English, because: & $\begin{array}{c}\text { Strongly } \\
\text { agree }\end{array}$ & Agree & Neutral & Disagree & $\begin{array}{l}\text { Strongly } \\
\text { disagree }\end{array}$ \\
\hline 1. & I want to travel overseas in the future. & 5 & 4 & 3 & 2 & 1 \\
\hline 2. & I want to further my studies in the future. & 5 & 4 & 3 & 2 & 1 \\
\hline 3. & $\begin{array}{l}\text { English can help me to make friends } \\
\text { with people of different nationalities } \\
\text { and background. }\end{array}$ & 5 & 4 & 3 & 2 & 1 \\
\hline 4. & $\begin{array}{l}\text { English can enhance my chances of } \\
\text { emigrating to other countries in the future. }\end{array}$ & 5 & 4 & 3 & 2 & 1 \\
\hline 5. & English is the way to gain more knowledge. & 5 & 4 & 3 & 2 & 1 \\
\hline 6. & English can raise my social status. & 5 & 4 & 3 & 2 & 1 \\
\hline 7. & $\begin{array}{l}\text { A good standard of English can help me do } \\
\text { better in other academic subjects as well. }\end{array}$ & 5 & 4 & 3 & 2 & 1 \\
\hline 8. & $\begin{array}{l}\text { English can help me to find a better job } \\
\text { in the future. }\end{array}$ & 5 & 4 & 3 & 2 & 1 \\
\hline 9. & $\begin{array}{l}\text { English can help me understand } \\
\text { Western culture. }\end{array}$ & 5 & 4 & 3 & 2 & 1 \\
\hline 10. & It can help me to broaden my horizons. & 5 & 4 & 3 & 2 & 1 \\
\hline 11. & $\begin{array}{l}\text { English can enable me to appreciate } \\
\text { Western films and music. }\end{array}$ & 5 & 4 & 3 & 2 & 1 \\
\hline 12. & It can satisfy my interests and curiosity. & 5 & 4 & 3 & 2 & 1 \\
\hline 13. & English is the mark of an educated person. & 5 & 4 & 3 & 2 & 1 \\
\hline 14. & It is part of my schoolwork. & 5 & 4 & 3 & 2 & 1 \\
\hline 15. & I like conversing with foreigners. & 5 & 4 & 3 & 2 & 1 \\
\hline 16. & I want to pass my public examinations. & 5 & 4 & 3 & 2 & 1 \\
\hline
\end{tabular}




\section{Personal questions}

Please circle the answers that apply to you.

\section{A. Gender:}

1. Male

2. Female

B. School level:
1. Form 4
2. Form 6

\section{Thank you very much for your help.}

Recebido em 10/03/09. Aprovado em 16/06/09. 